\title{
11 \\ Prehistoric sites in Kabupaten Enrekang, South Sulawesi
}

\author{
Hasanuddin
}

\begin{abstract}
Research on the prehistory of Enrekang, South Sulawesi, was conducted to find evidence of early human occupation in the region from the artefactual evidence preserved at various sites. A series of surveys was undertaken in sites at Mendatte, Buntu Banua and Buttu Batu, where there are traces of prehistoric habitation such as earthenware sherds, flaked stone artefacts, grindstones, hammerstones, barkcloth beaters and metal fragments. Test pits were excavated in the Buttu Batu rockshelter and revealed a basal habitation deposit that lacked earthenware pottery and an upper layer with abundant earthenware pottery. These results indicate a variety of activities suggestive of long-term settlement in the region from prior to the Neolithic and continuing to the Metal Age.
\end{abstract}

Keywords: prehistory, habitation, Buttu Batu, South Sulawesi, Enrekang

\section{Introduction}

The island of Sulawesi is located centrally within Indonesia, making it a strategic location for investigating cultural movements and developments. Its landscapes and seascapes have the potential to inform on the process of human migration and the introduction of domestic animals and crops, as well as human adaptation to the varying environmental and geological conditions within Sulawesi. South Sulawesi, in particular, has been shown to have a rich archaeological record from prehistoric to recent times (Simanjuntak and Widianto 2012).

Bulbeck (2004), writing on the survey and excavation results from Holocene sites in the South Sulawesi peninsula, synthesises the evidence into five phases from the early Holocene through to the Early Metal Phase as follows:

(a) the early Holocene, pre-7500 BP, characterised by stone tools of undistinguished quality across South Sulawesi

(b) the Early Toalean phase, between 7500-5500 BP, with the emergence of bone points and (in the southwest corner of Sulawesi) microliths

(c) the Late Preceramic Toalean phase, dating to 5500-3500 BP, marked by the appearance of Maros Points, also in the southwest corner of Sulawesi

(d) the Ceramic Toalean phase, from 3500-2000 BP, which saw the first Neolithic cultural traces emerging 
(e) the Early Metal Phase, between 2000-1000 BP, when evidence of kampongs and agricultural activities arose, associated with handicrafts and trade. This phase also saw the development of social classes which are clearly visible in the early history of South Sulawesi beginning at around $600 \mathrm{BP}$.

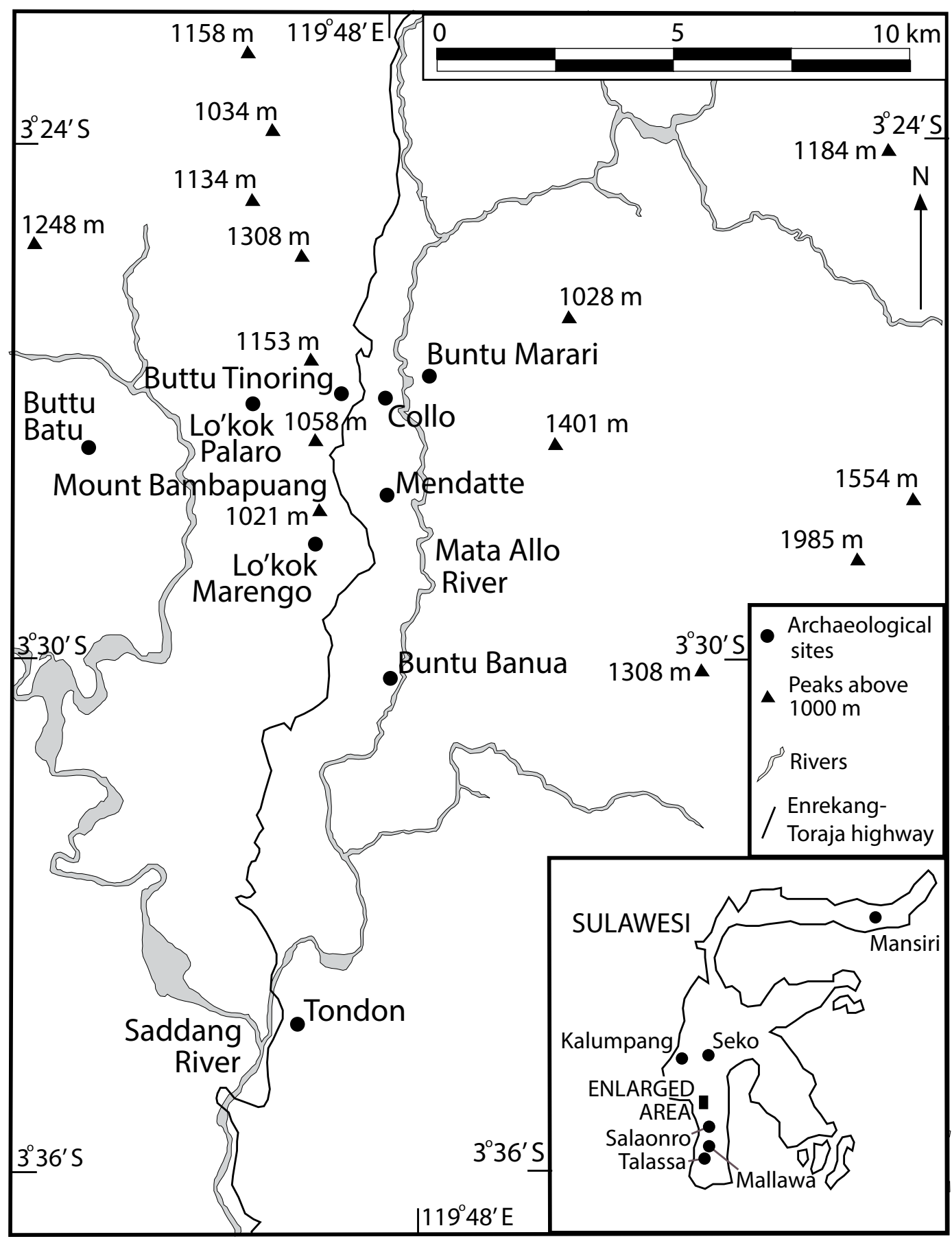

Figure 11.1: Sites and topographic features mentioned in the text.

Source: Base map from Duli (2013). 
Kabupaten (District) Enrekang is of relevance to this schema as it lies directly north of the South Sulawesi peninsula, whose archaeology was synthesised by Bulbeck. It is also of relevance for its intermediate location between the Neolithic settlements at Minanga Sipakko and Kamassi, Kalumpang, in West Sulawesi and Mallawa in the Maros hinterland of South Sulawesi (Figure 11.1). Neolithic radiocarbon dates for Minanga Sipakko range between 3690 160 BP (P3G-05) and 2570 $\pm 110 \mathrm{BP}$ (P3G-97) (Simanjuntak et al. 2008); for Kamassi they range between $3345 \pm 40 \mathrm{BP}$ (ANU 36406) and 2700 $\pm 150 \mathrm{BP}$ (Geolabs-411) (Anggraeni et al. 2014) and for Mallawa the range is $3580 \pm 130 \mathrm{BP}$ (P3G-06) to $2281 \pm 46 \mathrm{BP}$ (Wk-20380) (Mahmud 2008a; Hakim et al. 2009). These results point to the presence of Neolithic occupation sites in South and West Sulawesi between approximately 3500 and 2000 BP. Research undertaken in Enrekang between 2006 and 2011 by the Makassar Archaeology Office recovered a range of materials from prehistoric times through to the first influences of Islam (Somba 2009, 2011), but none of the habitation sites have been directly dated. Accordingly, this paper aims for indirect dating of these sites by comparing the archaeological finds from Enrekang with those from directly dated contexts elsewhere in Sulawesi.

\section{Background: Kabupaten Enrekang and overview of survey}

Enrekang District covers around $1,786 \mathrm{~km}^{2}$ or $2.83 \%$ of the total extent of South Sulawesi province. Much of the district is mountainous (about $85 \%$ ), with only small areas of rolling and flat landscapes. The mountainous regions are mostly in the north and central parts of Enrekang. The highest mountains are within the Latimojong and Bambapuang ranges. Mount Latimojong, also known as Mount Rantemario, has the highest peak in Sulawesi reaching 3478 metres above sea level ( $\mathrm{m}$ asl). The flat lowlands are found in the south near the Tempe (Bila) and Malino rivers, on the border with Sidrap District. The main river systems are the Saddang, Mata Allo, Maula and Tabang rivers, which wind their way across much of Enrekang; Saddang being the largest of these waterways extending over roughly $150 \mathrm{~km}$. All of these systems have been, and still are, integral to the lifeways of the region's inhabitants for drinking water as well as irrigation for their crops.

In 2006 and 2007, archaeological survey was undertaken near Mount Bambapuang (Figure 11.1) as well as an excavation at Collo where the survey had found earthenware pottery (Balar Makassar 2007). Two of the new sites discovered were the burial caves of Lo'kok Palaro and Lo'kok Marengo, and a third site was the open-air artefact scatter at Buttu Tinoring (Somba 2011). Collo is likely to be the oldest of these sites, possibly as old as Minanga Sipakko, based on its association of red-slipped pottery with coarse decorated pottery (incised triangles and impressed wavy designs) as well as flaked stone artefacts (Mahmud 2008b).

Additional field survey in 2008 resulted in investigation of the region's megalithic heritage at several sites, including Buntu Marari and Tondon (Figure 11.1). The range of recorded stone features (following the terminology defined by Hasanuddin 2015) included mortars, altars, stepped terraces, menhirs, dakon stones (with their chequerboard of circular depressions) and incised stones, demonstrating that the Enrekang area possesses a variety of megalithic styles (Hasanuddin 2011).

Although there are not yet any Carbon-14 dates for the sites described above, the material culture can be compared between sites in order to construct a relative chronology of the lifeways of the region's inhabitants. This approach is particularly useful when examining the stone artefacts from the Buttu Batu and Buntu Banua sites (see below). Also, absolute age determinations have been obtained on boat-shaped coffins with side planks and domed lids, known as duni or mandu, from Enrekang. In his research, Duli (2013) published Carbon-14 dates between 790 \pm 50 BP 
(Beta-274731, 659-893 cal BP) and 470 440 BP (Beta-274734, 343-622 cal BP) taken from the wood of the coffins in six burial caves $\left(l o^{\prime} k o k\right)$. Combining these results with the investigations into the prehistoric occupation of the Enrekang caves, we may infer that the original use of these caves as habitation sites changed to the storage of mortuary coffins prior to $700 \mathrm{BP}$.

\section{4 fieldwork overview}

In 2014, several sites were surveyed in an attempt to locate early human occupation sites in the Enrekang region. Three sites were chosen for further investigation-Mendatte open site, Buntu Banua cave and the Buttu Batu rockshelter. After reviewing the survey results from these sites, it was apparent that Buttu Batu, with its considerable variety in surface finds as well as its favourable location in the Mount Bambapuang landscape, had the greatest potential for multiphase occupation (Balar Makassar 2014).

\section{Mendatte open site}

Mendatte is located in the village (desa) of Rura in Kecamatan (Subdistrict) Anggeraja. The coordinates for the site are $03^{\circ} 28^{\prime} 13.0^{\prime \prime} \mathrm{S} 119^{\circ} 47^{\prime} 37.7^{\prime \prime} \mathrm{E}$, with an altitude of $389 \mathrm{~m}$ asl (Figure 11.2). The topographic conditions within the survey area are mostly steep slopes. The archaeological finds included stone artefacts and earthenware sherds. Ten limestone boulders that had been purposefully shaped into rough cubes were also found at or near the site. These stones were not arranged in an obvious pattern; however, they were evidently brought up from the river and shaped. It is possible that they had previously been placed beneath houses as pile supports or flagstones.

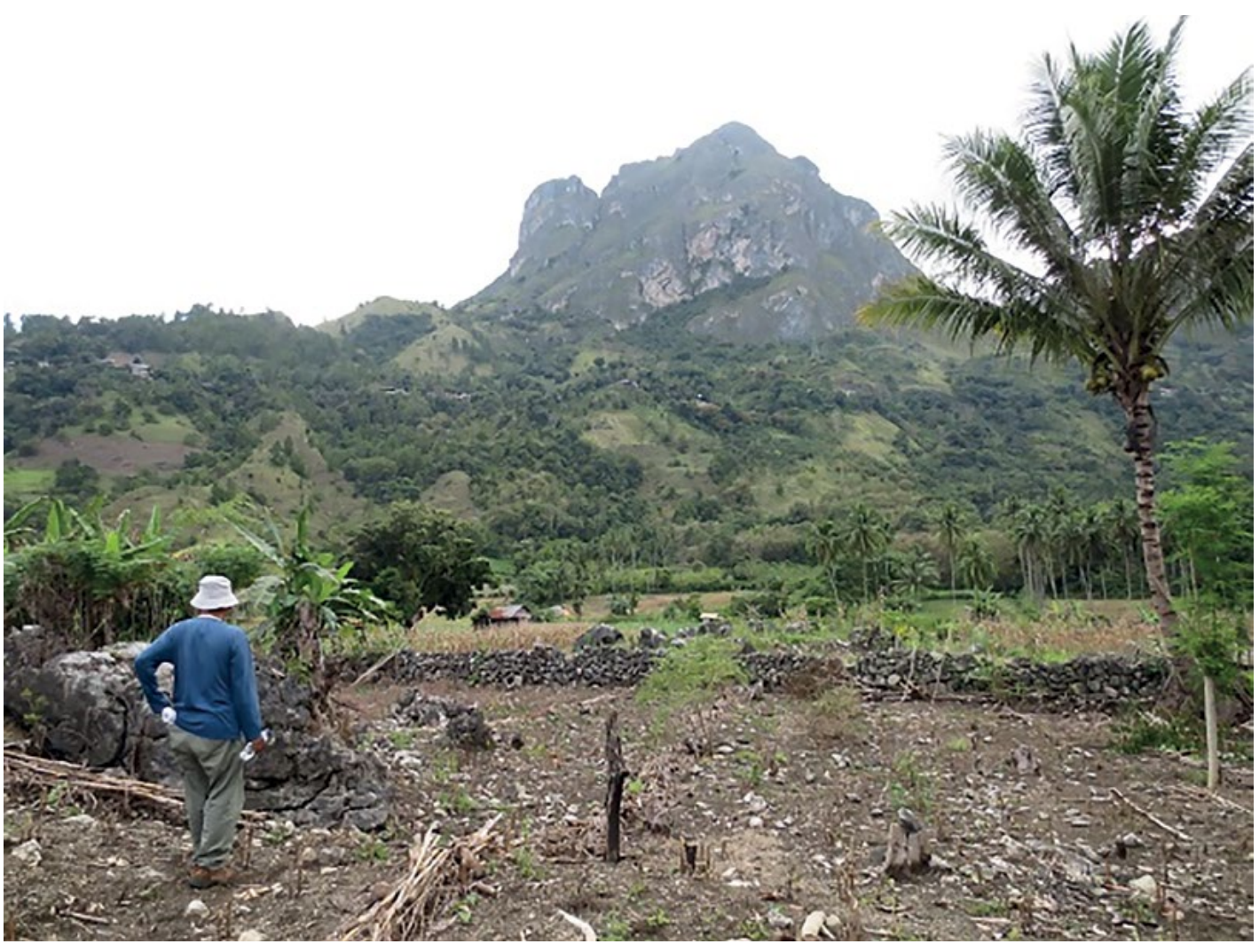

Figure 11.2: Mandatte open site located to the east of Mount Bambapuang.

Source: Balar Makassar (2014). 


\section{Buntu Banua cave}

Buntu Banua cave is located in the village (desa) of Kotu in Kecamatan Anggeraja with coordinates $03^{\circ} 30^{\prime} 10.3^{\prime \prime} \mathrm{S} 119^{\circ} 47^{\prime} 23^{\prime \prime} \mathrm{E}$, at $606 \mathrm{~m}$ asl. This cave is located on a hilltop and features two interconnected openings, one oriented to the northwest and the other to the east (Figure 11.3). The first of these openings is about $80 \mathrm{~cm}$ high and $7 \mathrm{~m}$ wide, while the second is $1.2 \mathrm{~m}$ high and $2.5 \mathrm{~m}$ wide. In front of the second entrance is a narrow depression about $34 \mathrm{~m}$ long that ends in a flat bottom between $0.5 \mathrm{~m}$ and $4 \mathrm{~m}$ deep. The cave floor is scattered with stones that are covered by limestone gravel and sediment. Geologically, the cave is no longer active and is void of any speleothems.

The surface materials collected during the 2014 survey included human remains (tibia, rib and femur fragments), animal bones, a barkcloth beater (batu ike), earthenware pottery fragments, river cobbles and midden material. These materials are consistent with the assemblage recovered from the site during previous fieldwork (Mahmud 2008b), which included a polished stone axe with round cross-section, a barkcloth beater and earthenware sherds that sometimes show the use of a slow potter's wheel. The pottery vessel forms had open to everted rims, variably with flat and curved lips, and some featured carinated bodies. Rim decorations included parallel diagonal incisions bracketed by rectangular panels or vertical lines, while the decorations on the vessel bodies included impressed fishnet patterns and impressed parallel lines.

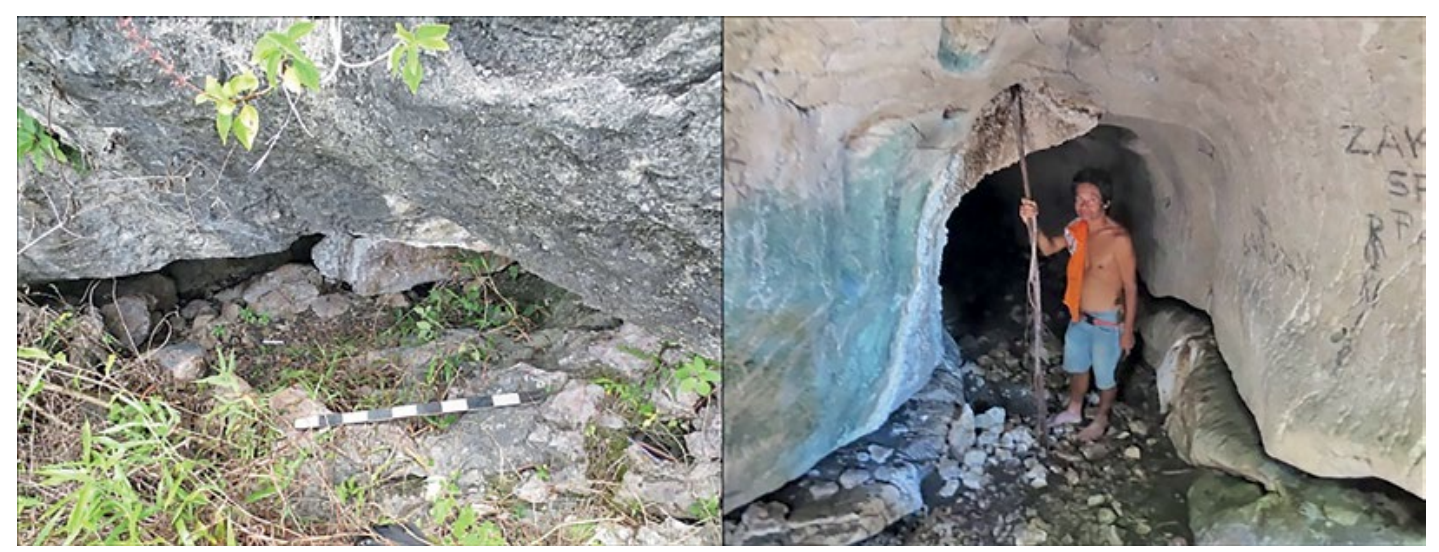

Figure 11.3: Entrances to Buntu Banua cave.

Source: Hasanuddin, Makassar Archaeology Office.

\section{Buttu Batu rockshelter}

Buttu Batu rockshelter is located near the village of Buttu Batu in Kabupaten Enrekang, $16.5 \mathrm{~km}$ from the regional capital of Enrekang, and northwest of Mount Bambapuang (Figure 11.4). The shelter is situated on a hilltop approximately $1.4 \mathrm{~km}$ east of and $280 \mathrm{~m}$ higher than the Saddang River. Two open-air 'sectors' to the southeast of the rockshelter were also surveyed for surface finds, and these are described here before describing the excavation of the rockshelter. 


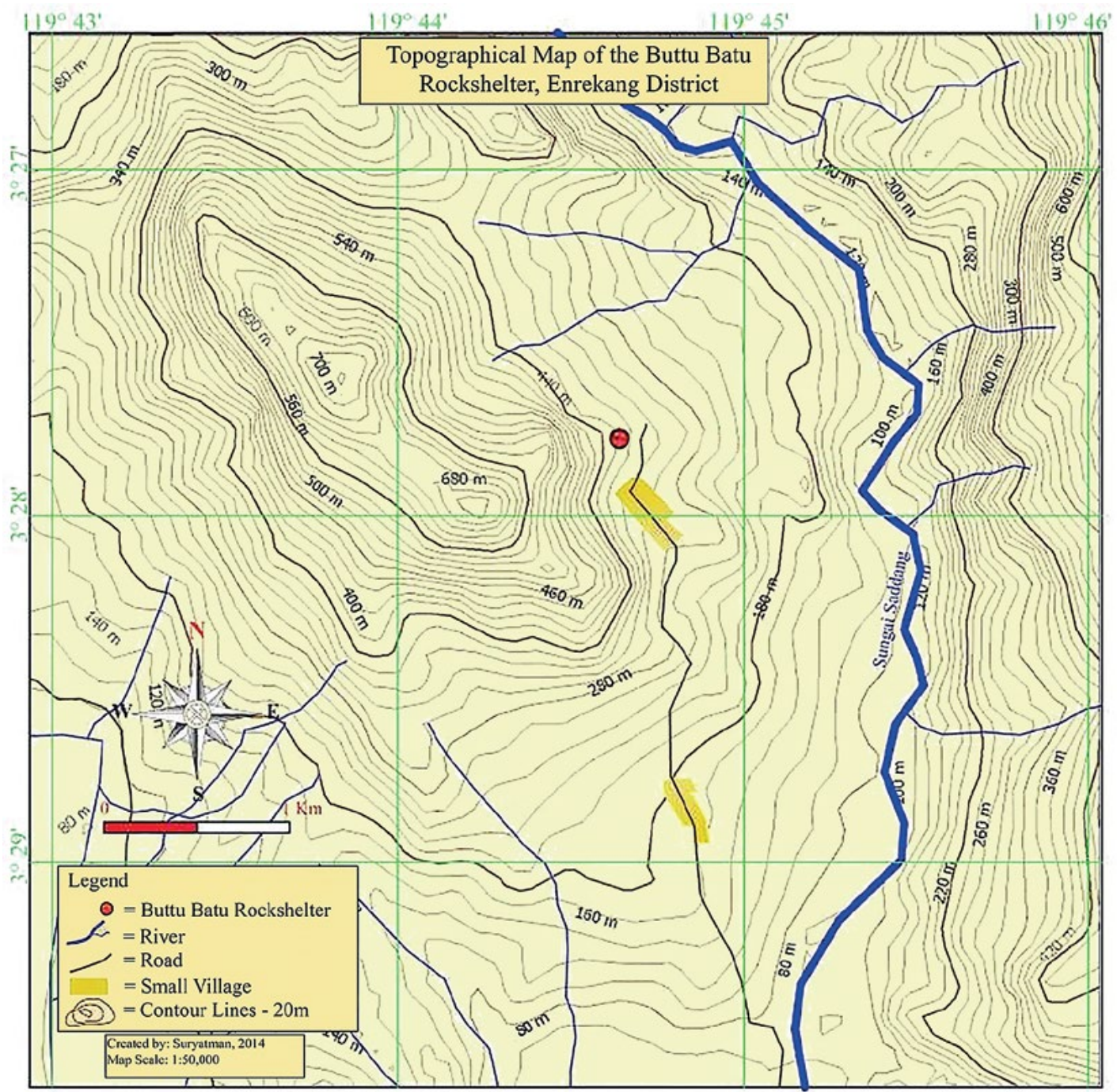

Figure 11.4: Topographic map with location of Buttu Batu Rockshelter.

Source: Suryatman, Makassar Archəeology Office.

Sector 1 has coordinates $03^{\circ} 27^{\prime} 58.2^{\prime \prime S} 119^{\circ} 44^{\prime} 44.9^{\prime \prime} \mathrm{E}$. It is situated on the mountainous slopes in an area near the road that has been previously used as gardens by the inhabitants of the Buttu Batu village to the south. The ground surface is overgrown by grass and littered with limestone blocks. Archaeological materials found in this sector included earthenware pottery sherds, river cobbles, flaked stone artefacts and a barkcloth beater.

Sector 2 of the surveyed area was located a short distance northwest of Sector 1 with coordinates $03^{\circ} 27^{\prime} 46.9^{\prime \prime} S 119^{\circ} 44^{\prime} 38.7^{\prime \prime} \mathrm{E}$ and an elevation of $383 \mathrm{~m}$ asl. This sector lies within a limestone outcrop on a steep slope and includes a cleft in the stone that is roughly $90 \mathrm{~cm}$ in width. The inhabitants use this area for growing teak (Tectona sp.) and kemiri trees (Aleurites moluccana, or candlenut). The recorded archaeological materials included stone artefacts, earthenware sherds (some coarse, some decorated and some with a red or a black slip), river cobbles, animal bones and teeth, shell midden material and corroded metal fragments. 


\section{Buttu Batu excavation data}

\section{Overview}

An excavation was opened at Buttu Batu site to document the cultural sequence and chronology. The excavation area, which was selected as it promised the greatest potential for the oldest habitation, was located about one metre behind the rockshelter opening, at the highest point inside the dripline (Figure 11.5a). Three contiguous $1 \mathrm{~m} \times 1 \mathrm{~m}$ squares were measured out with a west to east orientation. They were labelled U1-T1, U1-T2 and U1-T3 (Figure 11.5). The surface sloped where the excavation took place, with U1-T1 at the highest point and U1-T3 at the lowest.

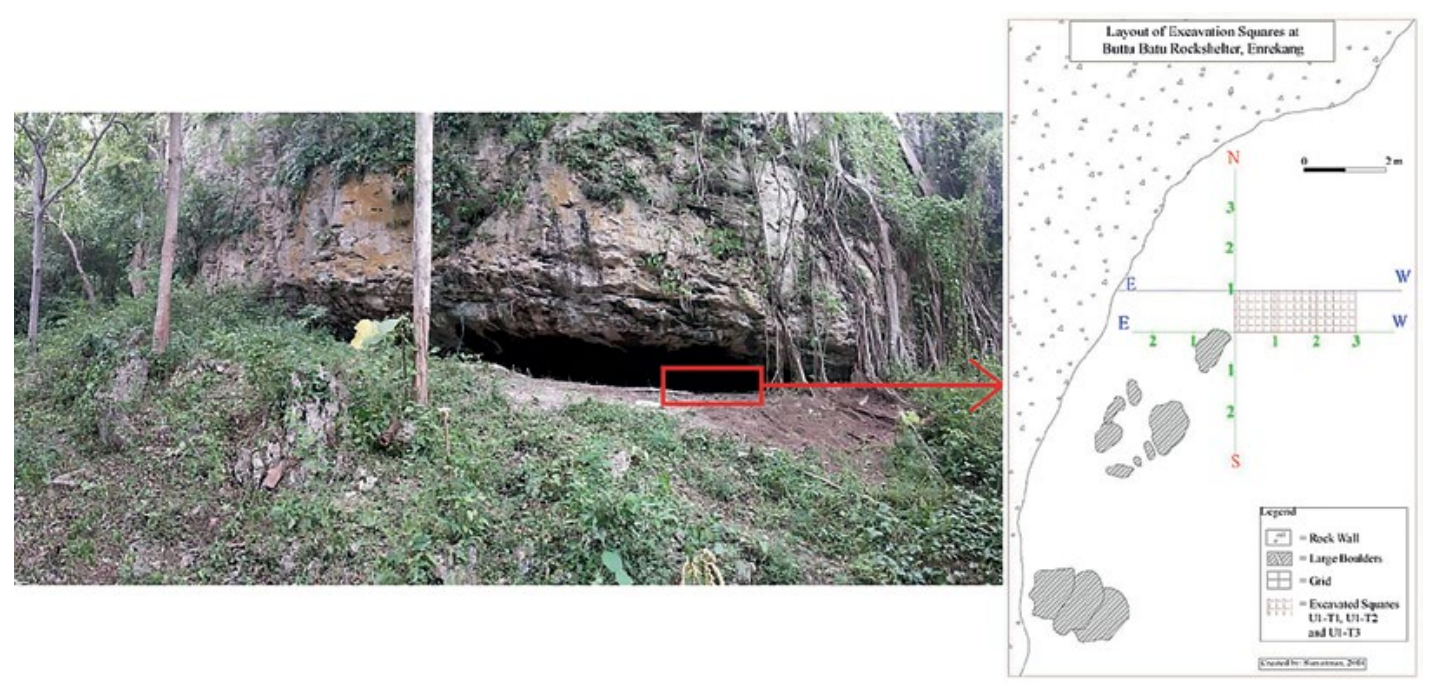

Figure 11.5: Photograph of Buttu Batu Rockshelter at Enrekang (left); A map of the excavated squares (right).

Source: Suryatman, Makassar Archaeology Office.

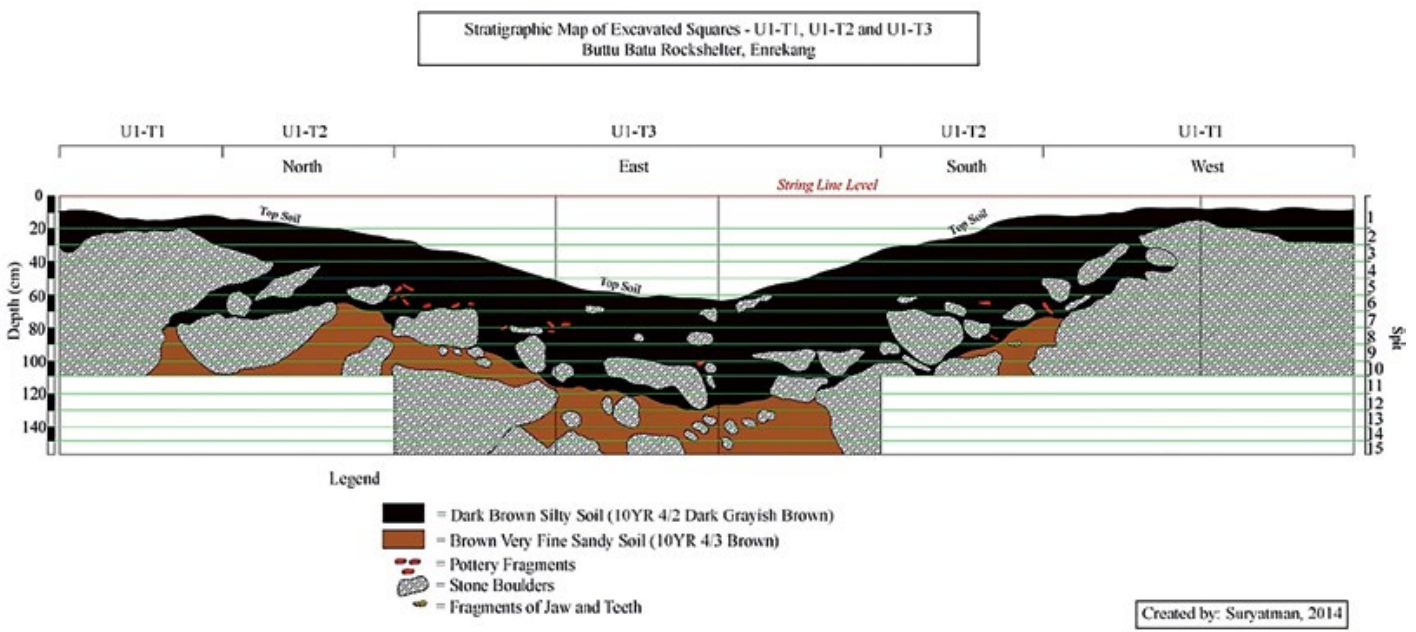

Figure 11.6: Stratigraphic map of U1-T1, U1-I3 and U1-T3 squares.

Source: Suryatman, Makassar Archaeology office. 
The excavation strategy was to remove sediment in $10 \mathrm{~cm}$ spits within the three $1 \mathrm{~m}^{2}$ squares. Spits were counted below a common datum, hence the first U1-T3 spit was recorded as Spit 3 along the western margin of U1-T3 but as Spit 5 along the test pit's eastern margin (see Figure 11.6). Considerable rock fall was uncovered in the excavation, particularly in U1-T1 and U1-T2, precluding excavation of the lower levels (Spits 11-15). The roof and the floor slope towards each other moving from U1-T3 (where there is sufficient room for standing erect) to U1-T1 (where space is cramped). These squares had a maximum depth of $110 \mathrm{~cm}$, whereas it was possible to excavate down to $160 \mathrm{~cm}$ beneath the datum in U1-T3. The excavation revealed two distinct cultural layers that are described below, and illustrated in Figure 11.6.

\section{Stratigraphic analysis and vertical distribution of the excavated materials}

The upper layer (Layer 1) consisted of dark brown silt (10 YR 4/2 dark greyish brown in Munsell chart terminology). The depth of this layer beneath the datum ranged between $10 \mathrm{~cm}$ to the west and $130 \mathrm{~cm}$ to the east, demonstrating a slope descending towards the east (as well as to the north and south). Boulders made up a large portion of the west wall and some of the north wall. Earthenware pottery sherds were common in the upper layer (Figure 11.6). Metal fragments were recovered from the surface of the upper layer but not from the excavated sediment; this may be due to unfavourable circumstances for long-term preservation of metal rather than an antiquity of the entire upper layer predating the Early Metal Phase.

The lower layer (Layer 2) was a very fine brown sand (10 YR 4/3 brown). Its uppermost extent occurred at $65 \mathrm{~cm}$ along the northern wall and it continued to the base of the excavation. Earthenware sherd quantities decreased as depth increased, where a transition occurred to flaked stone artefacts dominating the deposits. Midden materials including vertebrate (bone and tooth) fragments and shellfish were recovered from the excavation. Tables 11.1 and 11.2 below present the total weights of these excavated materials from U1-T1/U1-T2 (combined, to increase sample sizes) and U1-T3, respectively.

Table 11.1: Combined weights (grams) of earthenware sherds, flaked stone artefacts, bone and shellfish by spit for U1-T1 and U1-I2, Buttu Batu.

\begin{tabular}{|l|l|r|r|r|r|}
\hline Spit & Layer & \multicolumn{1}{|c|}{$\begin{array}{c}\text { Earthenware } \\
\text { sherds }\end{array}$} & \multicolumn{2}{c|}{$\begin{array}{c}\text { Flaked stone } \\
\text { artefacts }\end{array}$} & \multicolumn{2}{c|}{$\begin{array}{c}\text { Bone and tooth } \\
\text { fragments }\end{array}$} & \multicolumn{1}{c|}{ Shellfish } \\
\hline 1 & 1 & 3049 & 42 & 101 & 38 \\
\hline 2 & 1 & 2752 & 56 & 223 & 92 \\
\hline 3 & 1 & 2680 & 22 & 311 & 40 \\
\hline 4 & 1 & 2214 & 22 & 213 & 5 \\
\hline 5 & 1 & 7755 & 91 & 414 & 23 \\
\hline 6 & 1 & 4865 & 289 & 402 & 62 \\
\hline 7 & $1 / 2$ transition & 933 & 31 & 258 & 15 \\
\hline 8 & $1 / 2$ transition & 757 & 243 & 943 & 175 \\
\hline 9 & $1 / 2$ transition & 82 & 608 & 260 & 589 \\
\hline 10 & 2 & 25,087 & 484 & 193 & 110 \\
\hline Total & & 0 & 1888 & 3318 & 1149 \\
\hline
\end{tabular}

Source: Suryatman, Balai Arkeologi Makassar. 
Table 11.2: Weights (grams) of earthenware sherds, flaked stone artefacts, bone and shellfish by spit for U1-T3, Buttu Batu.

\begin{tabular}{|c|c|c|c|c|c|}
\hline Spit & Layer & $\begin{array}{c}\text { Earthenware } \\
\text { sherds }\end{array}$ & $\begin{array}{c}\text { Flaked stone } \\
\text { artefacts }\end{array}$ & $\begin{array}{l}\text { Bone and tooth } \\
\text { fragments }\end{array}$ & Shellfish \\
\hline 1 & - & - & - & - & - \\
\hline 2 & - & - & - & - & - \\
\hline 3 & 1 & 286 & 0 & 7 & 0 \\
\hline 4 & 1 & 707 & 13 & 62 & 0 \\
\hline 5 & 1 & 1082 & 0 & 168 & 0 \\
\hline 6 & 1 & 1775 & 4 & 260 & 0 \\
\hline 7 & 1 & 2427 & 43 & 208 & 10 \\
\hline 8 & 1 & 3102 & 121 & 79 & 0 \\
\hline 9 & 1 & 2792 & 381 & 101 & 77 \\
\hline 10 & $1 / 2$ transition & 857 & 0 & 62 & 142 \\
\hline 11 & $1 / 2$ transition & 76 & 115 & 76 & 67 \\
\hline 12 & 2 & 0 & 193 & 80 & 83 \\
\hline 13 & 2 & 0 & 108 & 55 & 50 \\
\hline 14 & 2 & 0 & 210 & 77 & 8 \\
\hline 15 & 2 & 0 & 46 & 148 & 32 \\
\hline Total & & 13,104 & 1234 & 1383 & 469 \\
\hline
\end{tabular}

Source: Suryatman, Balai Arkeologi Makassar.

Earthenware sherds (Figure 11.7) were found through the deposit in U1-T1/U1-T2, with gradually decreasing weights from Spits 1 to 4, then a marked increase in Spit 5, followed by a decline that continued into Spit 10 (Layer 2, where no pottery was recovered). In the lowerlying U1-T3, sherds began in Spit 3 and increased to a maximum in Spit 8. Quantities then decreased, and no pottery was recovered from Spits 12-15 (corresponding to Layer 2). Overall, pottery was most prevalent at the middle depths (Spit 5 in U1-T1 and U1-T2, Spits 8 and 9 in U1-T3), before decreasing in subsequent spits and disappearing all together by $100 \mathrm{~cm}$ beneath the surface of the deposit.

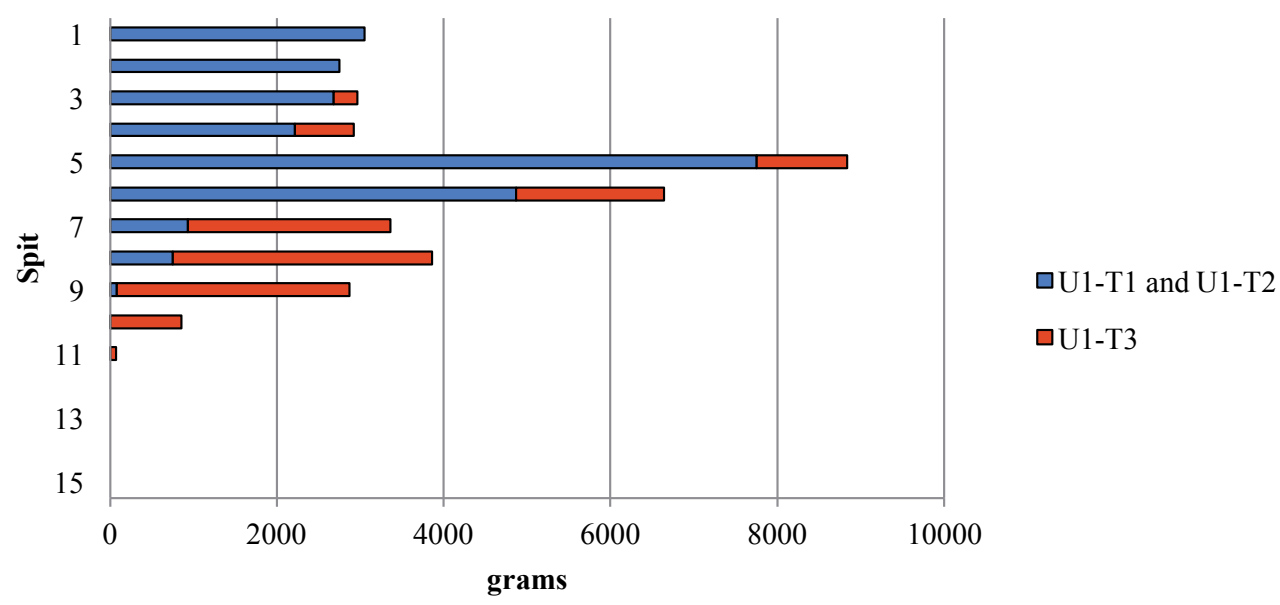

Figure 11.7: Bar graph showing the weights of the excavated pottery sherds by spit from Buttu Batu squares U1-T1, U1-I2 (blue) and U1-T3 (red).

Source: Data from Tables 11.1 and 11.2. 
The weights of flaked stone artefacts, osseous remains and shellfish in U1-T1/U1-T2 are presented in Figure 11.8. All are variably present within the deposit with larger quantities of each towards the basal spits, despite the decreased volume of excavated sediment owing to the increasing density of roof fall. Flaked stone was present in the uppermost spits but became more abundant in Spit 6. Spit 7 saw a sharp drop in stone artefacts followed by an increase again in Spits $8-10$, corresponding to the transition to Layer 2, with the largest quantity recovered from Spit 9. Bones and teeth were found throughout, but with the highest weights recorded in Spit 8. Shell was found in each spit and, like the stone artefacts, was most abundant towards the base of these squares, peaking in Spit 9.

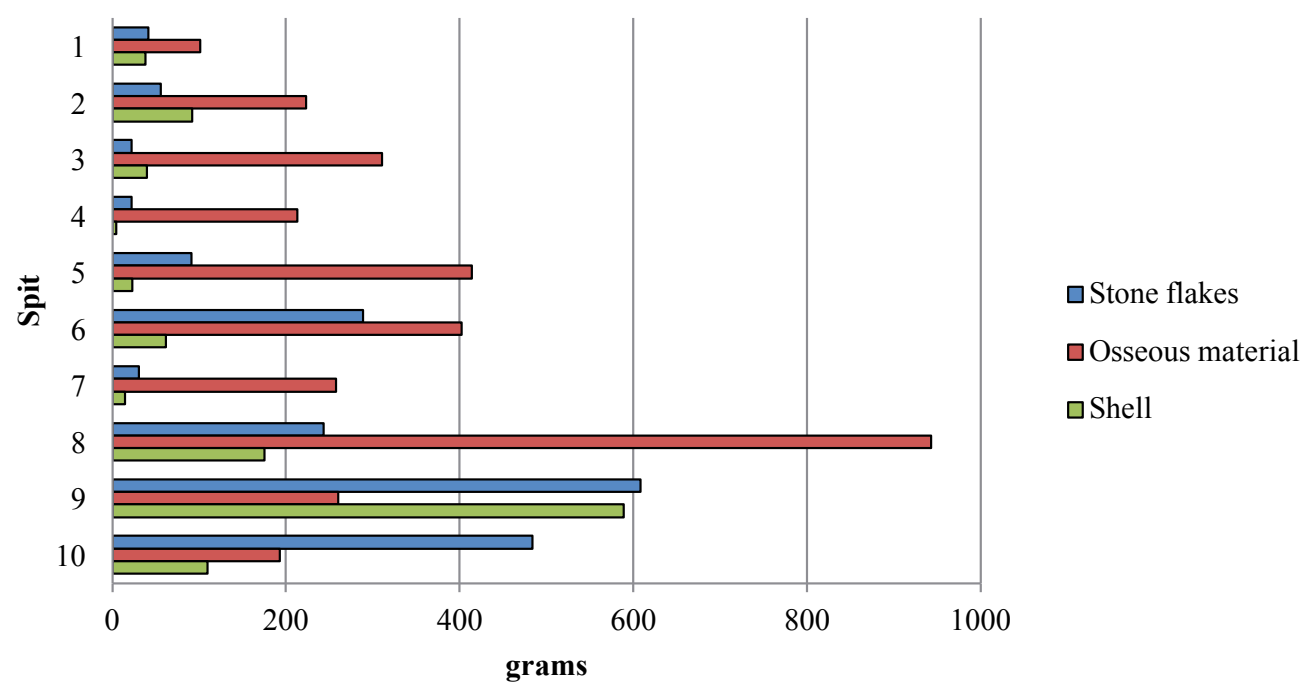

Figure 11.8: Bar graph showing the weights of flaked stone artefacts, osseous remains and shellfish in U1-T1 and U1-I2, Buttu Batu.

Source: Data from Table 11.1.

In square U1-T3 (Figure 11.9), flaked stone artefacts and osseous remains began appearing in Spits 3 and 4, reflecting the lack of excavated deposit above Spit 3 (Figure 11.6). Only small quantities of stone artefacts were retrieved from the upper levels before an increase in Spit 7 that peaked in Spit 9. No stone artefacts were recovered from Spit 10; however, they returned in subsequent spits (corresponding to Layer 2) with fair regularity. Osseous materials outweighed the stone artefacts in the upper spits of this square with the maximum amount in Spit 6 and then a return to steady abundance in lower spits. Shells did not appear until Spit 7 with none recovered again until Spit 9. Their prevalence in the deposit continued downwards with the greatest quantity of shell recovered from Spit 10.

Of particular interest were the barkcloth beater (batu ike), polished stone axe fragment and bone artefacts, all from U1-T1 and U1-T2 (Table 11.3). The first two of these were found in the pottery-bearing spits. As for the bone artefacts, two were found in Spit 3 and so may not be very old, whereas the third (from Spit 9) may be older than any of the pottery deposited at the site. 


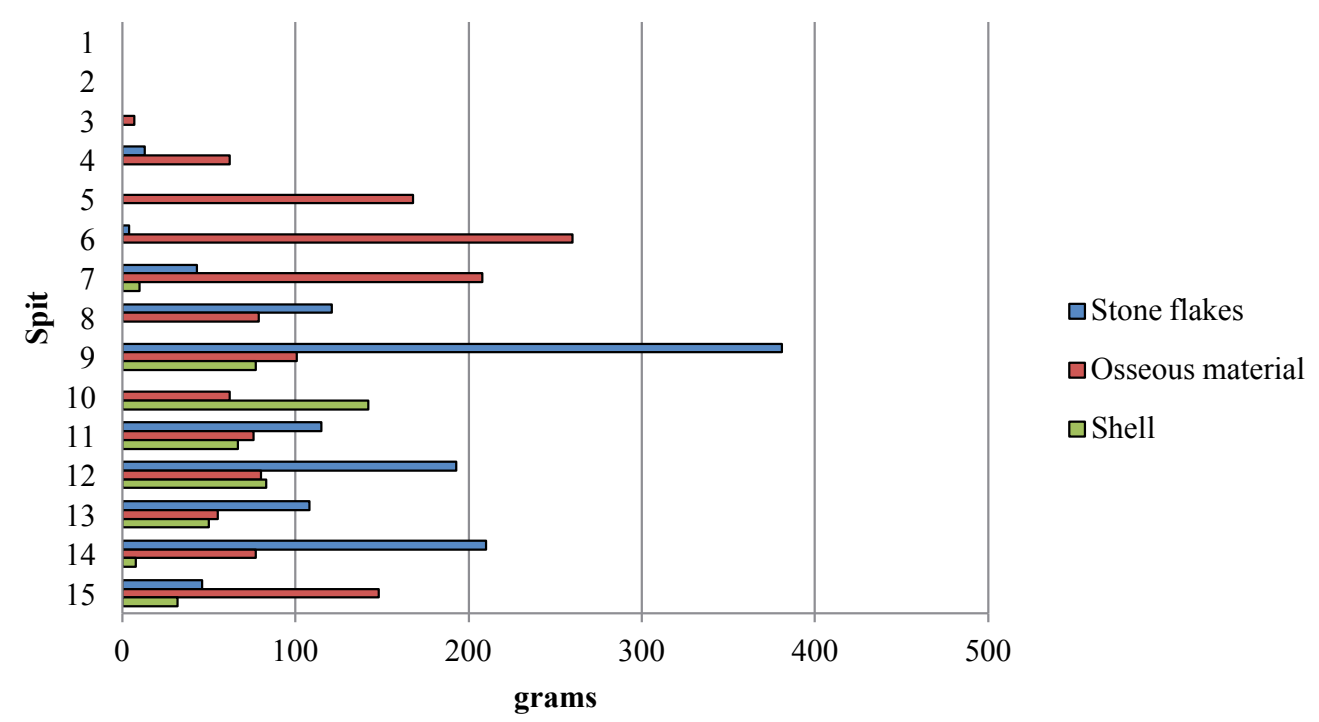

Figure 11.9: Bar graph showing the weights of flaked stone, osseous remains and shellfish in U1-T3, Buttu Batu.

Source: Data from Table 11.2.

Table 11.3: Spit Locations of the barkcloth beater (batu ike), stone axe fragments and bone artefacts in the U1-I1 and U1-I2 Squares (combined), Buttu Batu.

\begin{tabular}{|l|l|r|r|r|}
\hline Spit & Layer & Barkcloth beater & Stone axe & Bone artefacts \\
\hline 1 & 1 & 0 & 0 & 0 \\
\hline 2 & 1 & 0 & 0 & 0 \\
\hline 3 & 1 & 0 & 0 & 2 \\
\hline 4 & 1 & 0 & 0 & 0 \\
\hline 5 & 1 & 1 & 0 & 0 \\
\hline 6 & 1 & 0 & 0 & 0 \\
\hline 7 & $1 / 2$ transition & 0 & 0 & 0 \\
\hline 8 & $1 / 2$ transition & 0 & 1 & 0 \\
\hline 9 & $1 / 2$ transition & 0 & 0 & 1 \\
\hline 10 & 2 & 0 & 0 & 0 \\
\hline Total & & 1 & 1 & 3 \\
\hline
\end{tabular}

Source: Suryatman, Balai Arkeologi Makassar.

\section{Analysis of the earthenware pottery}

A total of 7527 earthenware sherds were analysed, including 5523 plain sherds (73\%) with no discernible decoration and 2004 decorated sherds (27\%). This proportion of decorated sherds is high. By way of comparison, the recorded proportion of decorated sherds in the Kalumpang sites is less than 10\%, and usually between $0-5 \%$ in all of the spits in Minanga Sipakko Trench III and Kamassi square K1 (Anggraeni et al. 2014); at the Neolithic site of Mansiri in North Sulawesi it is less than $1 \%$ (Azis et al., this volume).

The Buttu Batu motifs were divided into eight simple motifs and seven combination or complex motifs. The simple motifs included sets of parallel depressions and wavy incisions, overlapping zigzags, translations of circular depressions, scalloped rims, scored rims, lug holes (Figures 11.1011.12) and parallel vertical incisions (Figure 11.13). The complex motifs included combinations of circles, parallel horizontal and vertical lines, dentate (punctate) dots aligned in parallel format 
or inside triangles, zigzag incisions, lattice patterns filling rectangular panels, triangles filled with slanting lines, scored rims with a central furrow, and corrugated carinations (Figures 11.10 and 11.12). These motifs show some similarities to the Buntu Banua pottery decorations as described by Mahmud (2008b), such as parallel diagonal incisions, rectangular panels, fishnet (lattice) patterns and impressed parallel lines. On the other hand, similarities with the decorations on the Kalumpang Neolithic pottery are less clear. For instance, of the motifs listed in Table 11.4, both Buttu Batu and Kamassi have 15 motifs in their recorded repertoire, but only seven (47\%) in common.
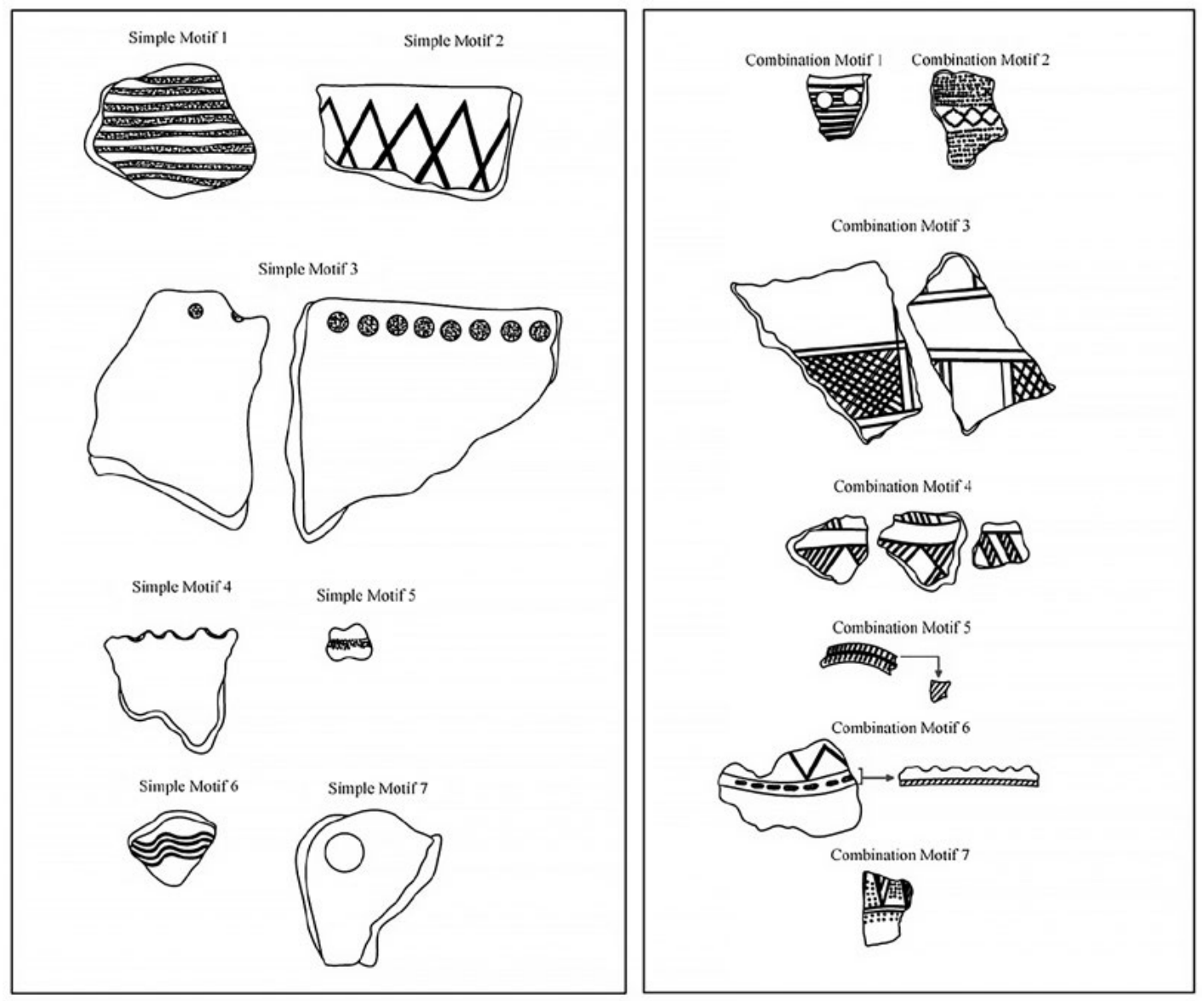

Figure 11.10: Varieties of simple and combination motifs on the pottery from Buttu Batu.

Source: Hasanuddin, Makassar Archaeology office.

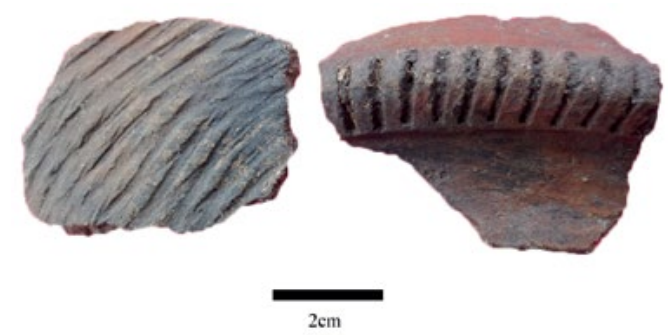

Figure 11.11: Simple Buttu Batu motifs 1 (left) and 4 (right).

Source: Hasanuddin, Makassar Archaeology Office.
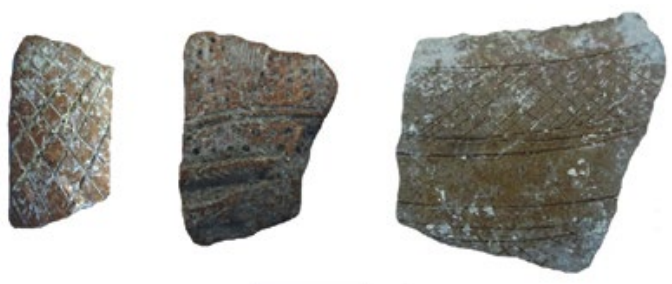

$2 \mathrm{~cm}$

Figure 11.12: Simple Buttu Batu motif 2 (left) and combination Buttu Batu motifs 2 (centre) and 3 (right).

Source: Hasanuddin, Makassar Archaeology office. 

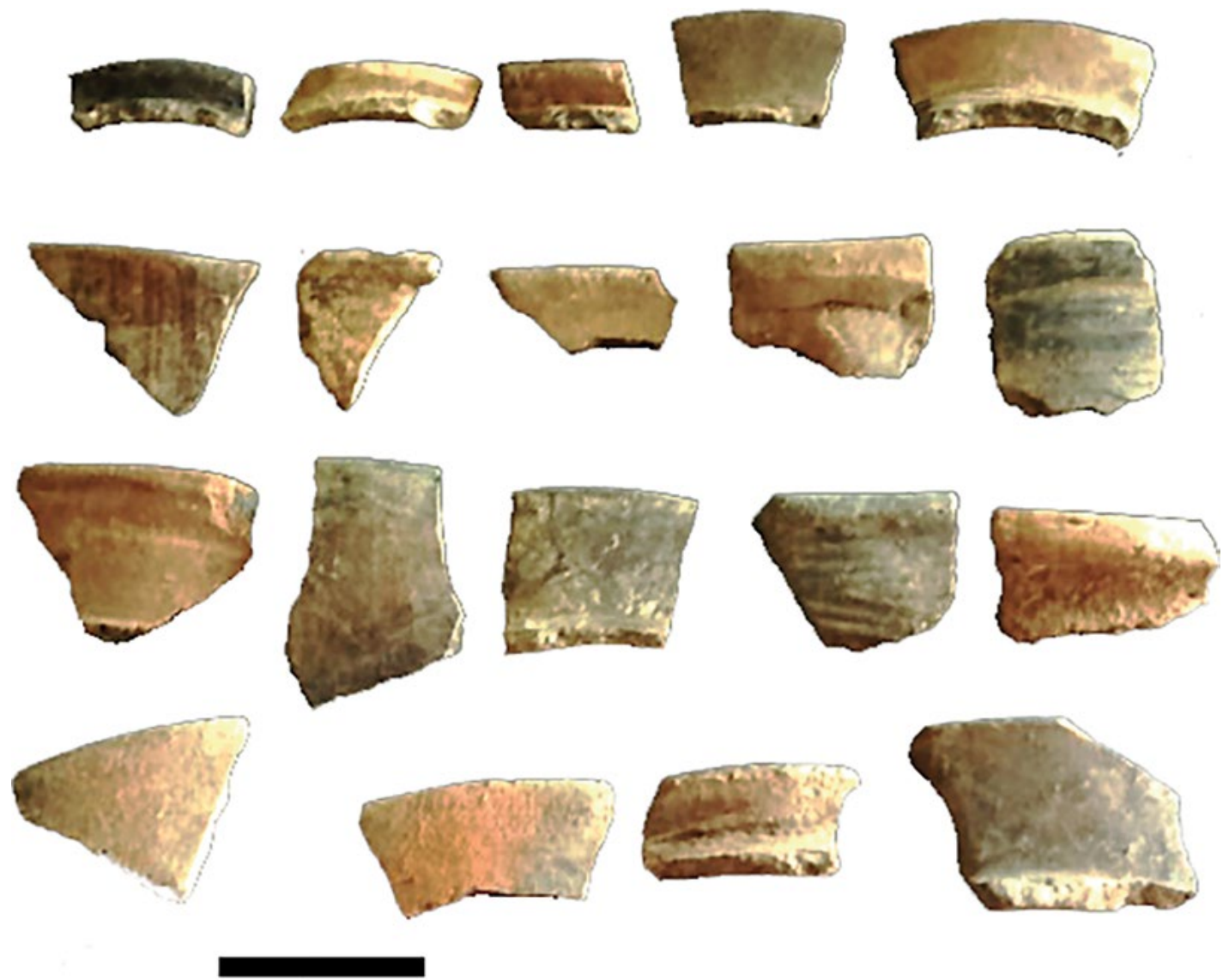

\section{$2 \mathrm{~cm}$}

Figure 11.13: Examples of the rim sherds from pottery found at Buttu Batu. Source: Hasanuddin, Makassar Archaeology office.

Table 11.4: Comparison of the Buttu Batu motifs with the Kalumpang (Minanga Sipakko and Kamassi) motifs.

\begin{tabular}{|c|c|c|c|}
\hline Motif & Buttu Batu & Minanga Sipakko & Kamassi \\
\hline Diagonal cross-hatching & $\sqrt{ }$ & $\sqrt{ }$ & $x$ \\
\hline Standalone diagonal incisions & $x$ & $\sqrt{ }$ & $\sqrt{ }$ \\
\hline Open circles & $\sqrt{ }$ & $\sqrt{ }$ & $x$ \\
\hline Filled circles & $\sqrt{ }$ & $x$ & $\sqrt{ }$ \\
\hline Double-stamped circles & $x$ & $\sqrt{ }$ & $\sqrt{ }$ \\
\hline Semi-circles & $x$ & $\sqrt{ }$ & $\sqrt{ }$ \\
\hline Parallel zigzags with vertical incised lines & $x$ & $\sqrt{ }$ & $x$ \\
\hline Other zigzag incisions & $\sqrt{ }$ & $\sqrt{ }$ & $x$ \\
\hline Zigzag lines of punctate points & $x$ & $\sqrt{ }$ & $x$ \\
\hline Lines of punctate points & $\sqrt{ }$ & $\sqrt{ }$ & $\sqrt{ }$ \\
\hline Triangular punctations & $x$ & $\sqrt{ }$ & $x$ \\
\hline Triangles filled with punctations & $\sqrt{ }$ & $\sqrt{ }$ & $\sqrt{ }$ \\
\hline Triangles with incised infill & $\sqrt{ }$ & $\sqrt{ }$ & $\sqrt{ }$ \\
\hline Right-angled triangles & $x$ & $\sqrt{ }$ & $x$ \\
\hline Parallel vertical incisions & $\sqrt{ }$ & $\sqrt{ }$ & $x$ \\
\hline Parallel horizontal incisions & $\sqrt{ }$ & $\checkmark$ & $x$ \\
\hline
\end{tabular}




\begin{tabular}{|c|c|c|c|}
\hline Motif & Buttu Batu & Minanga Sipakko & Kamassi \\
\hline Parallel slanting incisions & $\sqrt{ }$ & $\sqrt{ }$ & $\sqrt{ }$ \\
\hline Bone-shaped stamp & $x$ & $\sqrt{ }$ & $x$ \\
\hline Lunates & $x$ & $\sqrt{ }$ & $\sqrt{ }$ \\
\hline Arca shell impressions & $x$ & $\sqrt{ }$ & $\sqrt{ }$ \\
\hline Square/rectangular mazes & $x$ & $\sqrt{ }$ & $\sqrt{ }$ \\
\hline Waves & $\sqrt{ }$ & $\sqrt{ }$ & $\sqrt{ }$ \\
\hline Leaf designs & $x$ & $x$ & $\sqrt{ }$ \\
\hline Incised stylised human figures & $x$ & $x$ & $\sqrt{ }$ \\
\hline Pierced holes & $\sqrt{ }$ & $\sqrt{ }$ & $x$ \\
\hline Scalloped rims & $\sqrt{ }$ & $\sqrt{ }$ & $\sqrt{ }$ \\
\hline Scored rims & $\sqrt{ }$ & $x$ & $x$ \\
\hline Rectangular panels & $\sqrt{ }$ & $x$ & $x$ \\
\hline
\end{tabular}

Source: Figures 11.10-11.13 (this chapter); Prasetyo (2008).

The rims (Figure 11.13) were examined to investigate the vessel forms. Only rims that had more than $10 \%$ of the orifice preserved $(n=134)$ were considered complete enough to infer the shape of the whole pot and its type and potential use.

The dominant vessel form was cooking pots (periuk), with 80 identified $(60 \%$ of the analysed rims). The next most commonly identified forms were bowls or mangkuk (33\% of the sample, $\mathrm{n}=45$; Figure 11.14) and vases or jambangan (seven sherds or $5 \%$ of the sample). A cup (cawan) fragment and a fragment from a covered jar (tempayan tertutup) were also distinguishable.

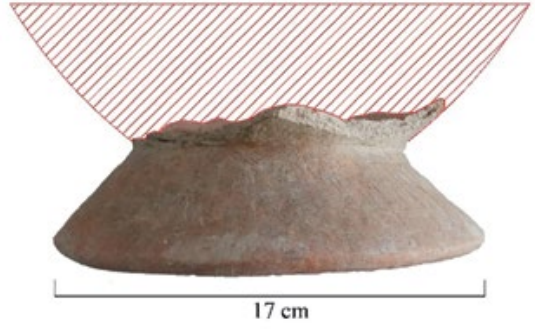

Figure 11.14: Reconstruction of a Buttu Batu bowl represented by its base.

Source: Hasanuddin, Makassar Archaeology Office.

\section{Analysis of the stone artefacts}

The excavation at Buttu Batu uncovered a number of stone artefacts produced using various technologies. Limestone, basalt and chert were the most common raw materials used to produce tools at the site. The artefacts recovered included cores, retouched and unretouched flakes, blades, polished axes and a fragment of a barkcloth beater (batu ike).

The term batu ike comes from the Kulawi and Biromaru communities in Central Sulawesi and describes a tool with deep parallel grooves that was used to turn the inner bark of the paper mulberry tree Broussonetia papyrifia into barkcloth (Bellwood 1978:139; Aragon 1990). The barkcloth beater fragment excavated at Buttu Batu was made from andesite and was $3.9 \mathrm{~cm} \times 3.3 \mathrm{~cm} \times$ $2.3 \mathrm{~cm}$ (Figure 11.15b). Its shape suggests it is of the Kalumpang type, one of the two barkcloth beater forms found in the region. Kalumpang barkcloth beaters generally have a squat cuboid shape with two main faces in the shape of shallow concave surface. There are grooves on one of the concave surfaces that is used to tether a rope connected to the butt of the stone. This type is very common in Sulawesi and Kalimantan (Indonesian Borneo). The other barkcloth beater form, the Philippine or horned type, has only one concave surface, which is striated, and a stone handle connected to the butt. This type is common in the Philippines (Soejono 1984) and also in Malaysian Borneo, such as the examples from Bukit Tengkorak (Chia 2003:62, 2015:46). 
There were four axe blanks and fragments found at the site that reveal a process of manufacture through the two steps of hammer dressing followed by polishing. Two of the axes had physical evidence of the hammer-dressing phase; the other two had polishing on one face. Two of the axes were made of andesite. The first was $4.5 \mathrm{~cm} \times 2.6 \mathrm{~cm} \times 0.7 \mathrm{~cm}$ and the other was $7.6 \mathrm{~cm} \times 4.1 \mathrm{~cm} \times 1.2 \mathrm{~cm}$. The other two axes were basalt. One measured $7.2 \mathrm{~cm}$ $\times 5.7 \mathrm{~cm} \times 1.6 \mathrm{~cm}$ and the final piece (Figure $11.15 \mathrm{a})$ was $6 \mathrm{~cm} \times 4.5 \mathrm{~cm} \times 1.3 \mathrm{~cm}$.

Flaked stone artefacts at this site were abundant. Flaking debitage dominates the flaked stone assemblage at Buttu Batu, which is a common feature of stone tool industries in eastern Indonesia (e.g. Simanjuntak and Widianto 2012:178). As well as 44 unretouched flakes in a range of shapes (Figures $11.15 \mathrm{c}$ and 11.16a-d), ventrally retouched flakes were recovered, one from Spit 3 and two from Spit 4 (Figure $11.15 \mathrm{~d}-\mathrm{e}$ ), as well as edge-trimmed flakes (Figure 11.17). Hammer stones with scarring on one surface were found in Spits 4 and 6 , and a grindstone was recovered from Spit 5. The site also contained the waste products from tool manufacturing such as debitage and cores (Figure 11.16e).
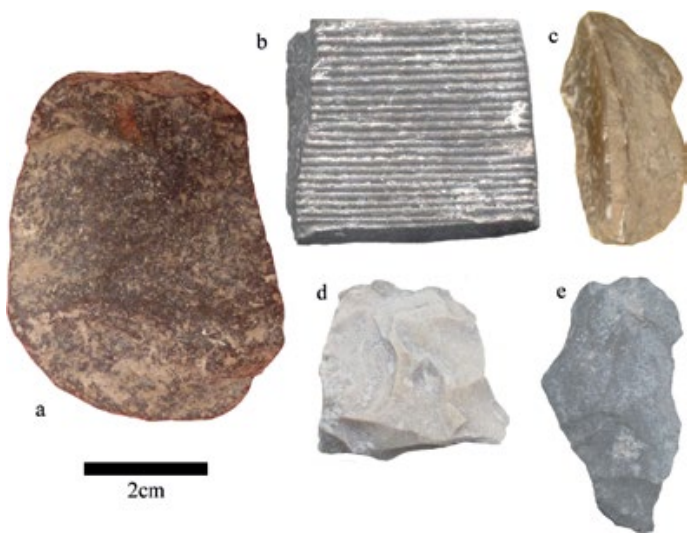

Figure 11.15: Stone artefacts found during

excavation at Buttu Batu: (a) stone axe blank, (b) barkcloth beater fragment (Spit 5), (c) abruptly-backed blade and (d-e) stone flakes with ventral retouch.

Source: Hasanuddin, Makassar Archaeology Office.
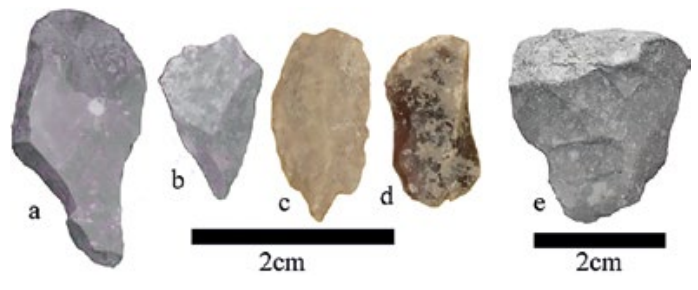

Figure 11.16: Stone artefacts found during excavation at Buttu Batu: (a-b) pointed flakes, $(c-d)$ blade-like flakes and (e) core.

Source: Hasanuddin, Makassar Archaeology office.

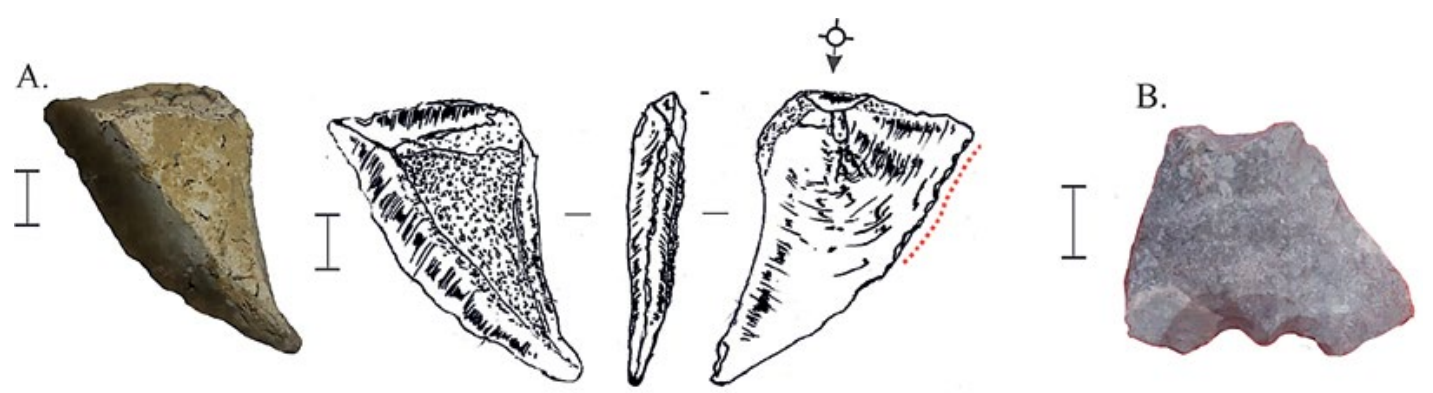

Figure 11.17: Edge-trimmed flakes from Buttu Batu of chert (A) and limestone (B). Source: Hasanuddin, Makassar Archaeology office.

The barkcloth beater (batu ike) and polished stone tools such as the axe blanks and fragments reflect a more complex use of stone artefacts during the Neolithic than during pre-pottery times. The Kalumpang type of barkcloth beater found at the Buttu Batu site is the usual form found in South Sulawesi, not only at Buntu Banua (Enrekang District) but also the Salaonro site (Soppeng District). It has also been recorded ethnographically as still in use at Seko in the northern part of Luwu, amongst other places. 


\section{Discussion}

The survey results of several sites in Enrekang District in South Sulawesi indicate a settled Neolithic lifestyle with artefactual evidence in the form of earthenware fragments, flaked stone artefacts, grindstones, river cobbles, stone axe fragments and barkcloth beaters. The Buttu Batu rockshelter is an occupation site with evidence of this kind on its surface. Excavation of the site revealed two occupation layers with abundant archaeological finds. For the most part, the upper layer contained artefactual finds similar to those on the surface, such as earthenware fragments, axe fragments and a barkcloth beater, which together reflect a prehistoric occupation with a Neolithic aspect.

On the other hand, the lower layer at Buttu Batu is a pre-pottery occupation level as there was an absence of sherds in Spits 12-15 in the U1-T3 square, as well as a marked decrease in the presence of sherds below Spit 6 in the U1-T1/U1-T2 squares. Remains of shellfish, bone and flaked stone remained plentiful throughout the excavation of the lower layer, even though the quantity of excavated deposit from each spit decreased due to the increase in boulders from past roof falls. These data indicate a late pre-pottery 'Mesolithic' habitation phase (Bulbeck et al. 2000) equating approximately to Spit 10 and below, despite the lack of any recovered Maros points (which are associated with the Mesolithic phase of the southwest of Sulawesi).

Remains of bone and, to a lesser degree, flaked stone and shell were recovered from the upper layer, along with large quantities of earthenware sherds, a barkcloth beater and a stone axe fragment. If we remember that there was little or no excavated deposit in the top two spits recognised for U1-T3, we can appreciate that the main classes of finds, notably the earthenware sherds (which constitute the dominant finds), are distributed throughout the layer. From the analysis of the stratigraphy of this upper layer and its artefact distribution, it is reasonable to suggest that it is a single assemblage, reflecting a single pattern of social behaviour (Deetz 1967:105-106). The set of activities reflected by the finds include making and using stone tools both in flaked and axe forms, using earthenware pottery, and making barkcloth—all of which suggest a settled lifestyle at or within the vicinity of the rockshelter.

However, in view of its isolated location and spatial constraints, the Buttu Batu rockshelter itself may not have hosted a settled population during the Neolithic. Instead, it may have served as a rockshelter for foragers who traded forest produce for pottery and other Neolithic items produced by their settled neighbours, or as a temporary camp for parties travelling out from settlements nearby (cf. Bulbeck 2004). Both uses of the site are possible, including a transition over time from the former to the latter, as suggested by the general decline in flaked stone artefacts and rise in earthenware sherds moving from the lower to the upper spits in Layer 1 (Tables 11.1 and 11.2).

The information from Buttu Batu presents a new perspective for our understanding of a Neolithic site on a high plateau of South Sulawesi. Although there are not yet any Carbon-14 dates to provide absolute dating, comparisons with sites that have produced technological and artefactual remains of the same kind (Simanjuntak 2008) suggest that the people who successfully occupied the Enrekang region partook of the same Neolithic culture as found at the open sites of Mallawa and Talassa in Maros, South Sulawesi, and those at Kalumpang in West Sulawesi. An initial date of -3500 BP has been proposed for the Neolithic in South Sulawesi and West Sulawesi, based on the dates associated with early pottery (Simanjuntak 2008), although whether this chronology would be applicable to the strongly decorated pottery from Buttu Batu may be a matter of contention. In any case, the Buttu Batu rockshelter also preserves deposits that reflect pre-Neolithic habitation prior to the appearance of pottery. This provides valuable information 
on the activities undertaken in the highlands of the northern part of South Sulawesi prior to the incursion into Sulawesi of Austronesian speakers with their Neolithic culture at around $3500 \mathrm{BP}$ (Simanjuntak 2008).

For the most part, Enrekang is an area dominated by hills and mountains that favour the development of agriculture. Mountain runoff and the large flowing rivers of the Saddang, Mata Allo, Maula and Tabang are integral for agricultural irrigation as well as providing fresh water to the region. The geographic situation of Enrekang works to create a dynamic and variable lifestyle, with its peaks interlaced by large flowing rivers that provide a laneway for interconnections and interactions with the outside world.

The Saddang River, which is navigable as far as Enrekang, in particular opened a vast area of the region to travelling peoples. Foot traffic through the hills along the Saddang River provided access to the Toraja highlands to the north of Enrekang, while river traffic connected Enrekang with the lowlands towards the south as far as the coast where the Saddang and its anabranches debouch. Along the coast, river entrances could be used for mooring boats, even in marshy areas, and as routes through the mangrove forest barriers (Pelras 1996:6). Indeed, the linguist Roger Mills proposed that the first speakers of South Sulawesi languages arrived by sea, not in a single migration but in a series of movements from an island nearby, attracted to the mouth of the Saddang River for the access it provided to trade routes into the hinterland (Pelras 1996:42). Pelras (1996:43) set the scenario proposed by Mills to the Early Metal Phase, shortly after 2000 BP, which would be too recent to apply to the Neolithic. Nonetheless, the major rivers of Sulawesi such as the Saddang may also have served as transport routes for the Austronesianspeaking immigrants arriving in the region (Azis et al., this volume).

\section{Conclusion}

The upper occupation layer at the Buttu Batu site produced finds (e.g. earthenware pottery, barkcloth beater, stone axes and flakes) similar to those associated with early Austronesian speakers in the Philippines and West Sulawesi (Anggraeni et al. 2014). The onset of this occupation phase may be comparable to the -3500 BP dating recorded for the Sulawesi Neolithic sites of Kalumpang and Mallawa. Importantly, the Buttu Batu sequence demonstrates that occupation in the Bambapuang area occurred prior to the introduction of pottery, as found widely elsewhere across the Indonesian Archipelago (Bulbeck et al. 2000). In the future, excavation should be extended deeper through the lower deposits with limestone boulders as far down as the earliest habitation deposit. In addition, absolute dating techniques should be applied in order to establish the chronology of pre-Neolithic and Neolithic settlement at the site, and the relationship with early occupation and the Neolithic transition as recorded at other sites in Sulawesi.

\section{Acknowledgements}

The author gratefully acknowledges the assistance of his colleague Suryatman at the Makassar Archaeology Office, who has provided tables and illustrative material with permission for their presentation here, and the helpful comments of two anonymous referees on an earlier draft of this contribution.

\section{Author biography}

Hasanuddin Makassar Archaeology Office, Makassar, South Sulawesi, Indonesia 


\section{References}

Anggraeni, T. Simanjuntak, P. Bellwood and P. Piper. 2014. Neolithic foundations in the Karama valley, West Sulawesi, Indonesia. Antiquity 88(341):740-756. doi: 10.1017/S0003598X00050663 (accessed 5 June 2018).

Aragon, L.V. 1990. Barkcloth production in Central Sulawesi. Expedition 32(1):33-48. anthropology.unc. edu/files/2018/02/Aragon-barkcloth-in-Sulawesi-color-Expedition-1990.pdf (accessed 9 March 2017).

Azis, N., C. Reepmeyer, G. Clark, Sriwigati and D.A. Tanudirjo. 2018. Mansiri in North Sulawesi: A new dentate-stamped pottery site in Island Southeast Asia. In S. O'Connor, D. Bulbeck and J. Meyer (eds), The Archaeology of Sulawesi: Current Research on the Pleistocene to the Historic Period, pp. 191-206. Canberra: ANU Press.

Balar Makassar. 2007. Laporan Survei dan Ekskavasi di Kawasan Bambapuang Kabupaten Enrekang. Unpublished report. Makassar: Makassar Archaeological Office.

Balar Makassar. 2014. Laporan Penelitian Arkeologi di Kabupaten Enrekang. Unpublished report. Makassar: Balai Arkeologi.

Bellwood, P. 1978. Man's Conquest of the Pacific. Sydney: Collins.

Bulbeck, D. 2004. Divided in space, united in time: The Holocene prehistory of South Sulawesi. In S. Keates and J.M. Pasveer (eds), Quaternary Research in Indonesia, pp. 129-166. Modern Quaternary Research in Southeast Asia, Volume 18. Leiden: A.A. Balkema.

Bulbeck, D., M. Pasqua and A. Di Lello. 2000. Culture history of the Toalean of South Sulawesi, Indonesia. Asian Perspectives 39(1-2):71-108. doi.org/10.1353/asi.2000.0004 (accessed 5 June 2018).

Chia, S.M.S. 2003. The Prehistory of Bukit Tengkorak as a Major Pottery Making Site in Southeast Asia. Kota Kinabalu: Department of Sabah Museum.

Chia, S.M.S. 2015. Arkeologi Bukit Tengkorak, Sabah. Pulau Pinang: Universiti Sains Malaysia.

Deetz, J. 1967. Invitation to Archaeology. New York: Natural History Press.

Duli, A. 2013. The mandu coffin: A boat symbol of ancestral spirits among the Enrekang people of South Sulawesi. Review of Indonesian and Malaysian Affairs 47(1):115-138.

Hakim, B., M. Nur and Rustam. 2009. The sites of Gua Pasaung (Rammang-Rammang) and Mallawa: Indicators of cultural contact between the Toalian and Neolithic complexes in South Sulawesi. Bulletin of The Indo-Pacific Prehistory Association 29:45-52. doi.org/10.7152/bippa.v29i0.9476 (accessed 5 June 2018).

Hasanuddin. 2011. Temuan megalitik dan penataan ruang permukiman di Kabupaten Enrekang, Sulawesi Selatan. Walennae 13(2):159-168.

Hasanuddin. 2015. Kebudayaan Megalitik di Sulawesi Selatan dan Hubungannya dengan Asia Tenggara. Unpublished PhD thesis, Centre for Archaeological Research Malaysia, Universiti Sains Malaysia, Kuala Lumpur. www.oxis.org/theses/hasanuddin-2015.pdf (accessed 5 June 2018).

Mahmud, I. 2008a. The Neolithic site of Mallawa. In T. Simanjuntak (ed.), Austronesian in Sulawesi, pp. 119-127. Jakarta: Center for Prehistoric and Austronesian Studies.

Mahmud, I. 2008b. The Neolithic and the ethnogenesis process of Enrekang. In T. Simanjuntak (ed.), Austronesian in Sulawesi, pp. 105-118. Jakarta: Center for Prehistoric and Austronesian Studies.

Pelras, C. 1996. The Bugis. Oxford: Blackwell. 
Prasetyo, B. 2008. Pottery from the Neolithic sites at the banks of Karama River. In T. Simanjuntak (ed.), Austronesian in Sulawesi, pp. 77-92. Jakarta: Center for Prehistoric and Austronesian Studies.

Simanjuntak, T. 2008. Austronesian in Sulawesi: Its origin, diaspora, and living tradition. In T. Simanjuntak (ed.), Austronesian in Sulawesi, pp. 215-251. Jakarta: Center for Prehistoric and Austronesian Studies.

Simanjuntak, T., M.J. Morwood, F.S. Intan, I. Mahmud, K. Grant, N. Somba, B. Akw and D.W. Utomo. 2008. Minanga Sipakko and the Neolithic of the Karama River. In T. Simanjuntak (ed.), Austronesian in Sulawesi, pp. 57-75. Jakarta: Center for Prehistoric and Austronesian Studies.

Simanjuntak, T., and Widianto, H. (eds). 2012. Indonesia dalam Arus Sejarah: Prasejarah. Jakarta: PT Ichtiar Baru van Hoeve.

Soejono, R. P. 1984. Sejarah Nasional Indonesia, Vol. 1. Jaman Prasejarah. Jakarta: Balai Pustaka.

Somba, N. 2009. Jejak-jejak arkeologis di kaki Gunung Bambapuang Kabupaten Enrekang, Sulawesi Selatan. Walennae 11(2):107-124.

Somba, N. 2011. Ciri budaya Austronesia di kawasan Enrekang Sulawesi Selatan. Walennae 12(1):1-10. 
This text is taken from The Archaeology of Sulawesi: Current Research on the Pleistocene to the Historic Period, edited by Sue O'Connor, David Bulbeck and Juliet Meyer, published 2018 by ANU Press, The Australian National University, Canberra, Australia.

doi.org/10.22459/TA48.11.2018.11 